\title{
Artigos
}

\section{O homem na língua ${ }^{1}$ The man in the language}

Maria Ines Pagliarini Cox ${ }^{*}$

\begin{abstract}
RESUMO: Neste estudo revisita-se um conjunto de estudos realizados por Émile Benveniste entre os anos de 1940 e 1970 em torno das categorias de pessoa, tempo e espaço. Focalizam-se as sucessivas retomadas das noções de sujeito e subjetividade e o processo de constituição da linguística da enunciação que excedeu os limites da chamada linguística imanente, ao reintroduzir elementos situacionais, parametrizados pelo ego-hic-nunc, na produção do sentido.
\end{abstract}

PALAVRAS-CHAVE: Émile Benveniste. Subjetividade. Linguística da enunciação

\begin{abstract}
This study revisits a set of studies carried out by Émile Benveniste between the years of 1940 and 1970 on the categories of person, time and space. It focuses on the successive retakes of the notions of subject and subjectivity and the process of constitution of the linguistics of enunciation which has exceeded the limits of the so-called immanent linguistics, by reintroducing situational elements, parametrized by the ego-hic-nunc, in meaning production.
\end{abstract}

KEYWORDS: Émile Benveniste. Subjectivity. Linguistics of enunciation.

\section{Introdução}

O que não se tentou para evitar, ignorar ou expulsar o sentido? É inútil: essa cabeça de medusa está sempre aí, no

centro da língua, fascinando os que a contemplam. Em vez de ziguezaguear com

o sentido e imaginar processos complicados - e inoperantes - para deixá-

lo fora do jogo retendo somente traços formais, é preferível reconhecer francamente que ele é condição indispensável da análise linguística (BENVENISTE, 1976, p. 130 e 131).

Este artigo é um tributo a Émile Benveniste, um linguista que conviveu com o estruturalismo francês, praticou-o, sem, contudo, ignorar a presença do homem na língua,

\footnotetext{
${ }^{1} \mathrm{O}$ título deste artigo retoma o nome da seção em que Émile Benveniste reúne os artigos sobre a enunciação nos volumes I e II da obra Problemas de Linguística Geral.

${ }^{*}$ Professora do Programa de Pós-Graduação em Estudos de Linguagem da Universidade Federal de Mato Grosso.
} 
diferença que fez dele um dos precursores da linguística da enunciação e/ou do discurso ${ }^{2}$. Ler o conjunto de artigos reunidos em Problemas de Linguística Geral I e II, principalmente aqueles constantes da seção L'homme dans la langue, é colocar-se em contato com um pensamento em ebulição, um pensamento que seria um divisor de águas na história da linguística moderna, um pensamento que vislumbrou regularidades no reino da fala, tida, até então, como não passível de se tornar um objeto científico pela sua volatilidade.

Muito provavelmente Benveniste não imaginava que sua revisão da categoria de pessoa nos verbos e pronomes desaguaria na linguística da enunciação que acabou por retomar o domínio semântico descartado pela chamada linguística imanente por implicar o falante e a situação de fala, ou seja, a instância do eu-aqui-agora. Seu gesto excedeu os limites da linguística da língua, uma vez que incorporou à produção de sentidos elementos exteriores ao sistema gramatical.

Benveniste foi um cientista muito produtivo. Conforme Ono (2007), ele publicou 18 livros, 291 artigos e 300 resenhas. A gama de temas abordados por ele é muito variada, mas tem como ponto de convergência a significação. Seus leitores são unânimes em apontar que a coerência de sua trajetória como linguista é a referência constante à significação que ele considerava a “cabeça de medusa” da língua(gem). De acordo com Normand (2009, p. 12), “o itinerário de Benveniste pode ser lido como aquele de uma fidelidade a Saussure, ao mesmo tempo que como uma ultrapassagem no sentido hegeliano do termo”, uma vez que ele vai além de seu mestre no que diz respeito à análise da língua como sistema significante.

A obra de Benveniste, além de vasta e pródiga em temas e perspectivas, é muito sedutora pela qualidade de sua escrita que em nada lembra a sensaboria do estilo inerente aos tratados de linguística. Abre-se, por isso, a várias possibilidades de leitura. O caminho a ser trilhado neste artigo inclui (seção 2) uma peregrinação pelo conjunto de estudos realizados pelo linguista entre os anos de 1940 e 1970 sobre as categorias de pessoa, tempo e espaço, focalizando as sucessivas retomadas das noções de sujeito e subjetividade que culminaram com o desenvolvimento da linguística da enunciação. Inclui também (seção 3) uma incursão pelas reflexões sobre a categoria de sujeito da enunciação feitas por Michel Pêcheux, tido como o

\footnotetext{
${ }^{2}$ Em Benveniste, vale lembrar, o termo ‘discurso’ ora é empregado genericamente como sinônimo de enunciação, ora especificamente como instância de enunciação pessoal que se opõe à 'história' (instância de enunciação impessoal).
} 
fundador da escola francesa de análise de discurso, uma escola que coloca sob suspeita o retorno ao humanismo.

\section{Benveniste: da linguística geral à linguística da enunciação}

Num sobrevoo pela obra de Émile Benveniste, ou simplesmente pelo sumário dos dois volumes de Problemas de Linguística Geral, depara-se com um 'linguista geral'. Seis partes compõem os livros: Transformações da linguística, A comunicação, Estruturas e análises, Funções sintáticas, O homem na língua e Léxico e cultura. Nos capítulos que compõem cada uma dessas partes, diferentes aspectos da língua(gem) - sincrônicos, diacrônicos, filológicos, estruturais, sintáticos, morfológicos, lexicais, semiológicos, semânticos, etc. - são estudados pelo linguista.

Não muito afastado de Ferdinand de Saussure no tempo, Benveniste com ele se identifica não apenas pela generalidade dos temas que elege estudar, mas também pelo método que adota em suas investigações. Como seu mestre, ele nos lembra de que a fundação da linguística como ciência se fez mediante imperativos metodológicos que romperam com o atomismo vigente na gramática histórica e comparada, tais como: não tomar por objeto a filosofia da linguagem, nem a evolução dessa ou daquela forma linguística, mas a língua em si; delimitar-se e definir-se a si própria, constituindo-se como ciência autônoma, formal e sistemática; não estabelecer normas, mas descrever; dispensar igual interesse a todos os tipos de línguas escritas ou não escritas; considerar, como princípio fundamental, que, sincronicamente, a língua é sempre um sistema; compreender o sistema como uma composição de elementos formais estruturados em combinações variáveis; rejeitar a ideia de que os dados da língua valem por si mesmos e são “fatos” objetivos, grandezas absolutas, suscetíveis de serem consideradas isoladamente; pressupor que as unidades linguísticas só se deixam determinar no interior do sistema que as organiza e domina, umas em razão das outras; ao invés de considerar cada elemento em si e de procurar sua "causa” num estado mais antigo, tomar cada elemento como parte de um conjunto sincrônico - o atomismo cedendo lugar ao estruturalismo (BENVENISTE, [1966] 1976, p. 21-23).

Protegido por esses princípios metodológicos, Saussure (1975, p. 16) enfrentou a complexidade da linguagem, ao mesmo tempo fisiológica e abstrata, social e individual, sincrônica e diacrônica, e fez da linguística uma ciência em sentido estrito. Foi a criação da dicotomia língua/fala que lhe permitiu, diante do “aglomerado confuso de coisas heteróclitas 
sem liame entre si”, vislumbrar a possibilidade de separar do fenômeno "linguagem” aquilo que, à época, lhe parecia passível de uma descrição sistemática - a língua. Com essa dicotomia, o linguista genebrino pode controlar a profusão de aspectos que matizavam a linguagem, elegendo a língua - social, ideada, sincrônica e sistemática - como princípio de unidade e classificação, em detrimento da fala - individual, física, diacrônica e contingente. Se, por um lado, a língua avultava como descritível e sistematizável, a fala, por outro, era transformada em lixeira da linguística onde se depositava tudo aquilo que se atribuía ao gênio maligno do sujeito falante. Por décadas, a fala só foi levada em conta como amostra por meio de que se podia atingir a língua. Para além disso, afirma Robin (1977, p. 25), a fala, “como domínio da liberdade e da criação, encruzilhada da Linguística, Psicologia ou Antropologia, foi abandonada [...] como reservatório de complexidades difíceis de ordenar e lugar em que se poderia desenvolver a subjetividade do locutor, mas mais ainda a do pesquisador”. A suposta liberdade do falante ao usar a língua decorria, primeiro, da concepção de sujeito indiviso, neutro e transparente a si próprio, anterior às descobertas freudianas que explodiram a unicidade da consciência, ao postularem a existência do inconsciente e, segundo, da concepção idealista de sujeito, imune às determinações sócio-histórico-ideológicas, anterior ao materialismo marxista. Conforme Robin (1977, p. 25), o sujeito falante não era nem o sujeito do 'isto fala', nem o sujeito do 'fala-se', era, sim, o sujeito do ‘eu falo’. Nesse caso, uma ciência da fala se revelava difícil ou mesmo impossível.

O florescimento da linguística da língua, nas primeiras décadas do século $\mathrm{XX}$, significou, assim, o desenvolvimento da fonologia, morfologia, sintaxe, ramos do chamado núcleo duro, mas não o da semântica. Pensavam principalmente os estruturalistas americanos, a exemplo de Bloomfield, que o essencial à língua era a forma e não o sentido. Rechaçado sob a pecha de aspecto mental, psicológico, subjetivo, o sentido foi negligenciado por essa linguística que contemplava apenas o aspecto formal da língua. Diz propriamente Benveniste ([1974] 1989, p. 229) sobre isso: “as manifestações do sentido parecem tão livres, fugidias e imprevisíveis quanto são concretos, definidos, descritíveis os aspectos da forma”. Se as manifestações de sentido eram livres, fugidias e imprevisíveis, então não podiam se constituir em objeto de estudo, não podiam ser descritas e sistematizadas.

Embora Benveniste fosse leal aos princípios da linguística da língua, desafinava no destino reservado por ela ao sentido. Para ele, o sentido não é de modo algum um detalhe irrelevante, mas o que de mais elementar há na língua(gem): “Que a língua signifique, isso quer 
dizer que a significação não é alguma coisa que lhe é dada por acréscimo, [...]; é seu próprio ser; se ela não fosse assim, ela não seria nada” (BENVENISTE, [1974] 1989, p. 219). Esse seu desencontro com a linguística formalista no tocante ao "esquecimento" do sentido não apenas expôs a fragilidade da tese da autonomia da língua em relação à situação de uso, como também encetou a criação de uma linguística da enunciação.

A concepção formal de signo como unidade que assimila um significante (imagem acústica) a um significado (conceito) e, por consequência, a concepção de língua como um tesouro de signos depositados na mente dos falantes de uma dada comunidade linguística tornam-se insustentáveis quando o que se estuda é a classe dos dêiticos. Os dêiticos, constituídos em torno do eu-aqui-agora (em latim ego-hic-nunc), remetem-se não a conceitos, mas a indivíduos cuja significação implica necessariamente a referência que, por sua vez, implica a situação de fala. Esse é o ponto de retorno do recusado, o ponto de retorno da fala, subsumida como enunciação.

O estudo de questões enunciativas envolve Benveniste, por mais de duas décadas, na desafiadora tarefa de levantar regularidades num domínio tido como heterogêneo, inconstante, impreciso, fluido, fugaz, em razão de sua dependência de um sujeito suposto livre com poder ilimitado de criação. Aliás, é em torno da noção de sujeito que a linguística da enunciação se constitui. Foram inúmeros estudos desde Structure des relations de personne dans le verbe, em 1946, até L'appareil formel de l'énonciation, em 1970, reunidos posteriormente em Problèmes de Linguistique Générale, volume I ([1966] 1976) e volume II ([1974] 1989), sob a rubrica L'homme dans la langue, título que, de uma certa forma, soa como uma resposta à polêmica vigente na vida intelectual francesa dos anos 1960 sobre o estruturalismo e a morte do homem.

O título L'homme dans la langue pode sugerir um ressurgimento triunfal do sujeito. Porém, não é assim que ele ressurge nos estudos linguísticos realizados por Benveniste. Investigando o sentido da categoria de pessoa nos verbos do francês, o linguista discorda do alinhamento uniforme em primeira, segunda e terceira pessoa, herdado da tradição gramatical grega. Para ele, esse princípio de classificação não informa nem sobre a necessidade da categoria e nem sobre as relações de sentido entre as diferentes pessoas. Como um linguista leal aos princípios saussureanos, propõe-se, pois, a descobrir “como cada pessoa se opõe ao conjunto das outras e sobre que princípio se funda a sua oposição, uma vez que não podemos atingi-las a não ser pelo que as diferencia” (BENVENISTE, [1966] 1976, p. 248). 
Em Estrutura das relações de pessoa no verbo (1946), Benveniste examina a morfologia verbal de várias línguas, inclusive daquelas aparentemente discrepantes, como o coreano, onde a categoria de pessoa poderia não ser indicada pelo verbo. Conclui que ela é inerente ao verbo, qualquer que seja a língua, embora possa haver particularidades no modo de expressá-la. Portanto, é uma categoria linguística universal e não uma idiossincrasia de línguas ocidentais, como o francês. Com relação à oposição entre as pessoas no interior do sistema, o linguista propõe uma revisão da classificação herdada dos gregos com base na interpretação dada a essa categoria pelos gramáticos árabes, assim configurada: al-mutakallimu 'aquele que fala', almuhatabu 'aquele a quem nos dirigimos' e al-ya'ibu ‘aquele que está ausente’ (BENVENISTE, [1966] 1976, p. 250).

Essa classificação realça a disparidade entre as duas primeiras pessoas (eu-tu) e a terceira (ele): as duas primeiras pessoas podem ser efetivamente ditas "pessoas”, ao passo que a terceira é o que está ausente, é uma “não-pessoa”. Para dar conta dessa primeira forma de oposição, Benveniste propõe a correlação de pessoalidade: “'eu-tu’ possui a marca da pessoa; ‘ele’ é privado dela” (BENVENISTE, [1966] 1976, p. 254). Embora essa correlação permita a diferenciação entre as pessoas e a não-pessoa, deixa no limbo a diferenciação entre as pessoas 'eu-tu'. Para completar a tarefa de distinguir linguisticamente a categoria de pessoa, propõe, então, a correlação de subjetividade: " $E u$ designa aquele que fala e implica ao mesmo tempo um enunciado sobre $e u$, dizendo $e u$, não posso deixar de falar de mim”, ao passo que “tu é necessariamente designado por eu e não pode ser pensado fora de uma situação proposta a partir do eu, e, ao mesmo tempo, eu enuncia algo como um predicado de tu.” (BENVENISTE, [1966] 1976, p. 250). Desse modo, no interior da correlação de subjetividade, eu se define como pessoa subjetiva e tu como pessoa não-subjetiva. Eu e tu são reversíveis, quer dizer, podem alternarse nas posições de locutor e alocutado num evento de fala. À primeira vista salta aos olhos a solução linguística que Benveniste deu à categoria de pessoa, raciocinando, como um bom estruturalista, em termos de estrutura, diferenças, oposição. Porém, o que se deseja sublinhar não é isso e sim a emergência da noção de subjetividade que se tornaria fulcral na constituição da linguística enunciativa.

Em A natureza dos pronomes (1956), a subjetividade transcenderá a visada linguística como o traço que opõe as pessoas eu e tu. Mediante constatação da universalidade dos pronomes, Benveniste passa a falar deles como um problema de linguagem e um problema de língua. Se se configura como um interessante problema de língua é porque constitui, antes, um 
problema de linguagem. É como fato de linguagem que se propõe a analisar os pronomes, partindo do princípio de que eles não constituem uma classe unitária: uns pertencem à sintaxe da língua, outros se remetem às instâncias de discurso que são atos discretos e únicos de apropriação da língua por um locutor. O linguista faz um contraponto entre os modos de significar do nome e da pessoa $e u$, concluindo que a diferença entre eles decorre do processo de enunciação linguística. Nomes implicam significações genéricas, constantes e objetivas, mas atualizáveis em objetos singulares. A significação de eu não implica nenhuma dessas propriedades. Já é sempre singular, define-se pela enunciação: "Eu é o indivíduo que enuncia a presente instância de discurso que contém a instância linguística ‘eu’”. Por sua vez, o tu é “o indivíduo alocutado na presente instância de discurso, contendo a instância linguística ‘tu’” (BENVENISTE, [1966] 1976, p. 279).

Destarte, Benveniste passa a definir a pessoa 'eu' como categoria de linguagem, que baliza a significação de uma série de indicadores de natureza pronominal, espacial e temporal como: eu, este, aqui, agora, hoje, ontem, amanhã, na próxima semana, há três dias etc., substituíveis respectivamente, quando passam da instância do discurso pessoal para a do relato impessoal, por: ele, esse, lá, então, no mesmo dia, na véspera, no dia seguinte, na semana seguinte, três dias antes etc. cuja significação independe da instância de enunciação, mas se remete aos objetos reais e tempos e lugares históricos. O significante ‘eu’ não se vincula a um ente da realidade e nem a um significado constante, como ocorre com outros signos da língua, mas sim à enunciação, a cada vez única, em que é enunciado. Segundo Benveniste ([1966] 1976, p. 280), a linguagem resolveu o problema da comunicação intersubjetiva “criando um conjunto de ‘signos vazios', não referenciais com relação à realidade, sempre disponíveis, e que se tornam plenos assim que o locutor os assume em cada instância de discurso”.

Os signos vazios funcionam como instrumento de conversão da língua(gem) em discurso. Assim, o emprego de eu-tu tem como condição apenas a situação de enunciação. Se, para exprimir sua subjetividade única e irredutível, cada locutor dispusesse de um significante distinto, à maneira das estações radiofônicas, "haveria tantas línguas quantos indivíduos e a comunicação entre eles se tornaria estritamente impossível”. Contudo, o risco de uma babel é neutralizado pela instituição de “um signo único, mas móvel, 'eu’, que pode ser assumido por todo locutor, com a condição de que ele, cada vez, só remeta à instância do seu próprio discurso” (BENVENISTE, [1966] 1976, p. 281). Enfatiza o linguista que o signo ‘eu’, com que o locutor 
se institui enquanto tal e em torno de que outros signos dêiticos se definem, diz respeito ao exercício da linguagem que é algo bem distinto da linguagem como sistema de signos.

$\mathrm{Na}$ perspectiva de Benveniste, a linguagem em exercício realiza-se sempre em instâncias de enunciação discretas. Contudo, essas instâncias nem sempre são pessoais. Há instâncias de enunciação que, apesar de discretas, se referem a uma situação constante e objetiva, do âmbito da não-pessoa. Quer dizer, a linguagem em exercício é produzida em instâncias discretas ora pessoais, ancoradas em 'eu', ora impessoais, ancoradas em 'ele'. Vale observar que essa distinção entre as instâncias discursivas pessoais e impessoais já anunciava a distinção entre discurso e história que o linguista iria propor em 1959.

É evidente a ampliação do escopo da noção de subjetividade em A natureza dos pronomes. Ela deixa de ser apenas um traço linguístico que opõe $e u$ a tu na correlação de subjetividade e passa a ser vista como uma categoria de linguagem que permite distinguir a língua como "repertório de signos e sistemas de suas combinações” da língua como "atividade manifestada nas instâncias de discursos” (BENVENISTE, [1966] 1976, p. 283). A chave para a compreensão da língua como um sistema de signos e suas combinações continua, como aprendera com Saussure, a ser a de "fato social", enquanto a chave para a compreensão da língua em exercício nas instâncias de enunciação é a de subjetividade. Nesse artigo, Benveniste dá mais alguns passos em direção a uma linguística da enunciação.

Em Da subjetividade na linguagem (1958), Benveniste começa problematizando a concepção de linguagem como instrumento de comunicação adotada por estruturalistas. Para ele, falar em 'instrumento’ é falar em algo que não existia até ser criado pelo homem. Não é isso que ocorre com a linguagem: "Não atingimos nunca o homem separado da linguagem e não o vemos nunca inventando-a. [...] É um homem falando que encontramos no mundo, um homem falando com outro homem, e a linguagem ensina a própria definição do homem” (BENVENISTE, [1966] 1976, p. 285).

De acordo com o linguista, o que faz da linguagem um instrumento apto à comunicação, à troca verbal, é a subjetividade que deve ser entendida como a capacidade que o locutor tem de se instituir como sujeito. O que, na linguagem, a predispõe à constituição da subjetividade? Primeiro, ela dispõe de formas linguísticas próprias à sua expressão, como: pronomes pessoais, indicadores dêiticos pronominais e adverbiais, tempos verbais, verbos modalizadores e performativos. Segundo, a linguagem em exercício se realiza em instâncias discretas, permitindo que o locutor, ao se apropriar da língua, designe-se como 'eu’. 'É na instância de 
discurso na qual ‘eu’ designa o locutor que este se enuncia como ‘sujeito’. É, portanto, verdade ao pé da letra que o fundamento da subjetividade está no exercício da língua” (BENVENISTE, [1966] 1976, p. 288).

Ademais, designar-se como 'eu’ é imediatamente dirigir-se a alguém que será, na alocução, um 'tu'. Enfim, a instituição das pessoas implica reversibilidade entre os papéis de locutor e alocutário: ‘eu’ me faço 'tu’ quando o 'tu” se faz 'eu’. Essa reversibilidade entre 'eu' e 'tu', inerente ao exercício da linguagem, é que é a condição da comunicação, do diálogo, e não a suposta instrumentalidade da palavra como pensavam estruturalistas. As duas pessoas não se concebem uma sem a outra: “Caem assim as velhas antinomias do 'eu’ e do 'outro', do indivíduo e da sociedade. [...] É numa realidade dialética que englobe os dois termos e os defina pela relação mútua que se descobre o fundamento linguístico da subjetividade” (BENVENISTE, [1966] 1976, p. 287).

Nesse estudo, Benveniste pensa a subjetividade como uma propriedade latente da linguagem pronta para se tornar patente no ato de enunciação quando alguém se apropria da língua e se nomeia 'eu'. Os dados de língua, as marcas formais, contam, meramente, como argumentos mediante os quais o linguista pode expor sua tese. Contudo, é inegável o tom humanista que aflora em afirmações, como "não há outro testemunho objetivo da identidade do sujeito que não seja o que ele dá assim, ele mesmo sobre si mesmo” (BENVENISTE, [1966] 1976, p. 288). É um Benveniste muito mais filósofo do que propriamente linguista que reflete sobre a subjetividade na linguagem neste texto.

Entretanto, em As relações de tempo no verbo francês (1959), o olhar do linguista parece ser reassumido. Ele deseja descobrir porque o francês dispõe de duas formas para a expressão do passado: il fit e il a fait. Um alinhamento uniforme dos tempos verbais em paradigmas conjugacionais, como o proposto pela gramática tradicional, não consegue explicar a razão dessa aparente redundância que tanto incomoda Benveniste. Assim, ele vai buscar uma explicação para o fenômeno na diferenciação dos planos enunciativos, retomando a dicotomia, proposta em 1956, entre instâncias enunciativas impessoais e pessoais, agora renomeadas como história e discurso respectivamente.

A história se caracteriza como "um modo de enunciação que exclui toda forma linguística ‘autobiográfica’. O historiador não dirá jamais ‘eu’ nem ‘tu’ nem ‘aqui’ nem ‘agora’ porque não tomará jamais o aparelho formal do discurso que consiste em primeiro lugar na relação de pessoa ‘eu-tu’” (BENVENISTE, [1966] 1976, p. 262). Assim, a narrativa histórica 
caracteriza-se pelo uso da não-pessoa 'ele' e de três tempos: o passado simples ou aoristo (il fit), o imperfeito (il faisait) incluindo o condicional (il ferait) e o mais-que-perfeito (il avait fait). O presente só aparece na acepção intemporal - o presente da definição. Nessa modalidade de enunciação, é como se os acontecimentos se narrassem a si mesmos.

Em contraponto à história, o discurso pode ser dito um modo de enunciação que inclui toda forma linguística ‘autobiográfica’. O enunciador dirá ‘eu’ e ‘tu’ e ‘aqui' e 'agora’ porque assumirá plenamente o aparelho formal do discurso que consiste em primeiro lugar na relação de pessoa 'eu-tu’. Além de empregar as pessoas ‘eu-tu’, não lhe é vetado o uso da não-pessoa 'ele'. Também pode empregar todos os tempos verbais, exceto o passado simples (il fit) que, no francês moderno, é característico da narrativa histórica. Em vez de il fit, o locutor recorrerá ao passado composto il a fait. Benveniste nomeia, pois, como discurso toda forma de enunciação subjetiva "que suponha um locutor e um ouvinte e, no primeiro, a intenção de influenciar, de algum modo, o outro” (BENVENISTE, [1966] 1976, p. 267).

Não se deve, entretanto, equivaler história à escrita e discurso à oralidade. A enunciação histórica ocorre preferencialmente na modalidade escrita da linguagem, mas o discurso pode ocorrer tanto na modalidade oral quanto na escrita: fala cotidiana, discurso na tribuna, correspondência, memória, teatro, literatura, jornalismo, obra didática etc., dentre outros usos da linguagem, podem ser ditos discursos, desde que o que dizem seja organizado segundo a relação ego-hic-nunc. Essa dicotomização dos planos enunciativos foi alvo de muitas críticas e revisões por parte de leitores de Benveniste que veem aí muito mais fluidez do que polaridade. Talvez, a polaridade tenha sido necessária para explicar que, entre il fit e il a fait, não há redundância, uma vez que a primeira é própria da narrativa histórica e a segunda do discurso, uma explicação que permite a reorganização das relações de tempo no verbo do francês. Eliminar supostas redundâncias do sistema é uma preocupação que motiva investigações conduzidas por estruturalistas, uma vez que, para eles, a língua só tem lugar para diferenças.

Todavia, a subjetividade, neste artigo de 1959, reveste-se de certa ambiguidade: por um lado, tem o estatuto de um traço distintivo mediante o que se dicotomiza/tipologiza os planos da enunciação em história e discurso e em função de que se reorganizam as relações de tempo no paradigma verbal do francês; por outro, matiza-se de um tom humanista, ao ser relacionada com o 'autobiografar-se'. Buscando uma solução ao gosto da linguística vigente à época, Benveniste a transborda e dá mais um passo na direção da linguística enunciativa. 
Em Os níveis da análise linguística (1962), o linguista inicia uma démarche que se firmará definitivamente nos estudos subsequentes mediante o que todo o precedente se reacomoda. A discussão acerca dos níveis da língua leva Benveniste a distinguir as unidades da língua das unidades do discurso, entendido, genericamente, como 'exercício de linguagem' e não apenas como um tipo específico de instância enunciativa. Da ordem da língua são os signos e, da ordem do discurso, as frases. A passagem da língua ao discurso envolve dois tipos de relações: constituintes e integrantes. No discurso, a frase porta constituintes, mas não pode funcionar como integrante. Na língua, o merisma funciona como integrante, mas não porta constituintes. Entre a língua e o discurso, estão os signos que tanto são integrantes quanto portam constituintes.

Benveniste equaciona constituinte e integrante a forma e sentido respectivamente: “A forma de uma unidade linguística define-se como sua capacidade de dissociar-se em constituintes de nível inferior. O sentido de uma unidade linguística define-se como sua capacidade de integrar uma unidade de nível superior” (BENVENISTE, [1966] 1976, p. 135 e 136). No nível da língua, o sentido de um signo é pensado como distintivo, opositivo e circunscrito em relação aos outros do mesmo sistema linguístico, ao passo que, no nível do discurso, o sentido de uma frase transcende o sistema, envolvendo o mundo dos objetos, as situações concretas, ou seja, a referência. Sentido e referência são coisas distintas, mas associam-se no nível da frase. A frase define-se por constituir um predicado, mas não entra em relações opositivas, por isso, não se pode falar em 'frasemas' como unidades distintivas, a exemplo dos ‘fonemas' e 'morfemas'. As frases comportam signos, mas não são elas mesmas signos. Signos constituem um conjunto finito; frases, um conjunto infinito: “A frase, criação indefinida, variedade sem limite, é a própria vida da linguagem em ação” (BENVENISTE, [1966] 1976, p. 139).

Em vista dessas características, Benveniste afirma que a 'frase' não só pertence ao discurso como é sua unidade básica. É uma unidade completa, pois porta, ao mesmo tempo, sentido e referência. Se o sentido diz respeito ao signo, ou seja, à significação que lhe está sistemicamente atrelada, a referência diz respeito a uma determinada situação. Nos termos de Benveniste ([1966] 1976, p. 140), aqueles “que se comunicam têm justamente isto em comum, uma certa referência de situação, sem a qual a comunicação como tal não se opera, sendo inteligível o ‘sentido’ mas permanecendo desconhecida a ‘referência”. 
A partir desse estudo, Benveniste avança um pouco mais na discussão da viabilidade de se instituir uma segunda linguística que, ao lado da primeira, dedicada ao estudo do signo e da língua, se incumbiria da análise da frase e do discurso. Essas duas linguísticas fariam caminhos opostos. A linguística da língua vai da diversidade infinita, importuna, dispersiva da fala às unidades constantes, recorrentes, limitadas, compartilhadas que os falantes de uma dada língua empregam e reencontram, ou seja, os signos. A linguística da enunciação iria da constância e comunidade do signo à contingência e individualidade das frases.

Essas duas linguísticas são retomadas em A forma e o sentido na linguagem (1966), Estruturalismo e linguística (1968) e Semiologia da língua (1969) como 'semiótica' e ‘semântica’ respectivamente. Enquanto a unidade linguística básica da semiótica é o signo, a da semântica é a frase. À semiótica não interessa saber o que o signo significa, mas se ele é reconhecido como signo pelos falantes de uma dada língua. Por exemplo, os falantes de português reconhecem 'gato', 'pato' e 'mato' como signos da língua que falam, mas não reconhecem 'zato' e 'Ihato'. Todo saber semiótico advém da consideração da língua como universo fechado e autônomo - “Quem diz semiótico, diz intralinguístico” (BENVENISTE, [1974] 1989, p. 223). Na imanência do sistema linguístico, o signo difere do signo, ser significativo equivale puramente a ser distintivo. Ao passar do signo para a frase, passa-se automaticamente do domínio da semiótica para o domínio da semântica. Ao falar desses dois domínios, Benveniste ([1974] 1989, p. 224) sublinha a diferença que há entre a dicotomia semiótico/semântico, proposta por ele, e a de língua/fala, proposta por Saussure. Como já mencionado anteriormente, a unidade básica da semântica é a frase. E, nesse domínio, não cabe perguntar aos falantes de uma dada língua se a frase significa, mas sim o que ela significa, isso compreendendo a intenção do locutor e a conversão de seu pensamento em expressão linguística. Diferentemente da semiótica que se limita à realidade intrínseca da língua, a semântica se abre para o fora da língua, já que o sentido de uma frase só é dado pela articulação do significado próprio do signo à referência (o contexto, a situação do discurso) e à atitude do enunciador. A dupla semiótica/semântica permite compreender que, se, por um lado, a língua se constitui no fechamento do mundo dos signos, por outro, ela se desloca em direção àqueles que a dizem e ao que dizem.

À luz das dicotomias signo/frase, sentido/referência e semiótica/semântica, a subjetividade reaparece não mais como um traço distintivo ligado ao funcionamento da categoria de pessoa em verbos e pronomes, ou como uma fronteira entre instâncias enunciativas 
impessoais e pessoais, ou seja, entre história e discurso, mas sim como algo essencial e inalienável ao segundo termo (frase, referência, semântica). Se o domínio do semiótico é o domínio do que há de comunal, social e compartilhado na língua, o semântico é o domínio do que há nela de individual, pessoal, subjetivo. Dessa forma, é-se levado a pensar no 'sujeito' como aquele que converte o modo de existir semiótico da língua no modo semântico, cada vez que se apropria dela para o exercício da função enunciativa. O estudo do domínio semiótico pode se servir da teoria saussureana do signo, mas o do domínio semântico demanda um aparato conceitual novo, esboçado por Benveniste em $O$ aparelho formal da enunciação.

O aparelho formal da enunciação (1970) é o ponto culminante do percurso feito por Benveniste até chegar à linguística da enunciação. Nesse estudo, o linguista reúne todos os aspectos relativos à enunciação explorados isoladamente em estudos precedentes, propondo-se a descrever as condições de emprego da língua. Pressupõe que essas condições são necessárias e permanentes e afetam a língua toda e toda língua, diferentemente das condições de emprego das formas que variam segundo o sistema linguístico a que pertencem. Definir as condições de emprego da língua equivale a "definir a enunciação no quadro formal de sua realização" (BENVENISTE, [1974] 1989, p. 83). Para a descrição desse quadro, é preciso considerar o próprio ato de enunciar, as situações onde se realiza e os instrumentos disponíveis para a conversão da língua em discurso.

O ato de enunciar introduz aquele que enuncia na própria enunciação e faz disso o fundamento mesmo das outras condições. Antes que ocorra a enunciação, a língua é apenas uma possibilidade. A enunciação envolve, pois, um processo de apropriação da língua: “O locutor se apropria do aparelho formal da língua e enuncia sua posição de locutor por índices específicos, de um lado, e por meio de procedimentos acessórios, por outro”. Ao se declarar locutor e se apropriar da língua, imediatamente "implanta o outro em face dele, qualquer que seja o grau de presença que se atribua a este outro”. Isso significa que a “enunciação é, explícita ou implicitamente, uma alocução”, ou seja, ela põe em relação “duas 'figuras’ igualmente necessárias, uma fonte, a outra fim da enunciação”. Trata-se de uma estrutura dialógica: "Duas figuras em posição de parceiros são alternadamente protagonistas da enunciação" (BENVENISTE, [1974] 1989, p. 81-85).

Também as situações são fundamentais na definição do quadro enunciativo, uma vez que o ato de enunciar faz explodir o fechamento inerente ao sistema linguístico e religa a língua ao mundo. As situações tornam a referência presente tanto ao locutor quanto ao alocutor, o que 
é uma condição indispensável para a interpretação do que é enunciado, pois apenas a compreensão do sentido do signo não é suficiente para a comunicação. Assim, o ‘eu’ precisa referir e o 'tu’ co-referir “identicamente no consenso pragmático que faz de cada locutor um co-locutor. A referência é parte integrante da enunciação” (BENVENISTE, [1974] 1989, p. 82). Por exemplo, um bilhete entregue a um morador de um edifício, assim redigido: "Estive aqui, mas não te encontrei. Ligue para mim à noite. Abraço”, pode ser linguisticamente compreensível, mas pragmaticamente é problemático. Ele deixa uma série de interrogações: quem esteve aqui, a quem é endereçado o bilhete, a quem o destinatário do bilhete deve ligar à noite? Para que essas questões sejam respondidas é preciso recuperar algumas coordenadas da situação de enunciação. Se o bilhete trouxesse algumas informações sobre a situação, como em “Mana, estive aqui, mas não te encontrei. Ligue para mim à noite. Abraço, Paula”, seria possível descobrir que o ‘eu’ que enuncia é Paula, que é irmã da destinatária, uma vez que a invoca como 'mana'. E é para Paula que a mana (te) deve ligar à noite. Esse exemplo mostra o quão dependente da enunciação é a interpretação de um enunciado. Um enunciado sempre pressupõe uma enunciação situada que precisa ser recuperada para garantir a sua interpretação.

Entre os instrumentos que fazem parte do aparelho formal da enunciação e têm a função de tornar as situações presentes nos enunciados estão as categorias de pessoa e de tempo e os índices de ostensão. Ao lado das entidades nominais que têm na língua estatuto pleno e permanente e se remetem sempre a conceitos, há os 'indivíduos linguísticos' - os chamados dêiticos - que a enunciação agencia em relação ao eu-aqui-agora do locutor. Os indivíduos linguísticos "são engendrados de novo cada vez que uma enunciação nova é proferida, e cada vez eles designam algo novo” (BENVENISTE, [1974] 1989, p. 85). A enunciação é ainda responsável pela tripartição dos enunciados em declarativos, imperativos e afirmativos, classificação baseada na atitude do locutor em relação a quem e àquilo que fala. Quaisquer outras formas de modalização do enunciado que denunciem atitudes do enunciador fazem parte do aparelho formal da enunciação.

O que dizer então do sujeito e da subjetividade na perspectiva globalizante do aparelho formal da enunciação? Revisitar o percurso que vai de 1946, com a publicação de Estrutura das relações de pessoa no verbo, até 1970, com a publicação de O aparelho formal da enunciação é acompanhar o processo de generalização da categoria de sujeito. Nesse estudo de 1970, o sujeito é visto como a chave com que se pode descerrar o continente de emprego da língua, ainda quase perdido na suposta multiplicidade sem limites da fala, à aventura, tão cara 
aos cientistas, de esquadrinhar e de levantar invariantes naquilo que aparecia, no nascedouro da linguística moderna, como variação infinita. A invariante da língua em emprego é nada menos do que a subjetividade, o sujeito, o ‘eu’ e a rede de indivíduos e modalizadores que agencia.

Esse resultado soa paradoxal porque, apesar de rever a dicotomia língua/fala em termos dos domínios semiótico/semântico, Benveniste parece abraçar a mesma concepção de sujeito que fez Saussure deixar a fala de quarentena, um sujeito a que o linguista genebrino agregava predicados como: individualidade, vontade, consciência, inteligência, unicidade, tudo na contramão do que exigia a ciência linguística à época - a escritura do repetível, do regular. Conforme Haroche (1983, p. 141), a linguística se esforçava para "afastar o contingente, o não repetível, tradicionalmente imputados ao sujeito”. Era de se esperar que, ao ensaiar o passo em direção à linguística da fala, Benveniste sentisse necessidade de se desvencilhar desse sujeito que, ao se apropriar da língua no ato de enunciação, a fazia variar infinitamente, tornando-a refratária à apreensão de regularidades por um método científico. Porém, é em torno dessa concepção de sujeito que a linguística da enunciação se inicia.

\section{Do sujeito da enunciação à forma-sujeito do discurso}

Num jogo ambíguo que não deixa perceber claramente quem vem primeiro, a pessoa, o sujeito ou a linguagem, Benveniste consegue o que parece impossível - fazer da subjetividade a categoria nuclear à teoria da enunciação. Se é o ‘eu’, o sujeito, na qualidade de um substrato a priori e permanente que causa e sustenta cada ato como determinação sua, que se põe como fundante da subjetividade na língua(gem), então a possibilidade de uma linguística da enunciação é muito remota. O linguista parece enveredar por esse caminho quando estabelece uma relação de causa e efeito entre sujeito, de um lado, e 'ação', 'vida', 'movimento' e ‘criação’, de outro. Assim: a) “o locutor (no ato de produção de um enunciado) mobiliza a língua por sua conta” (BENVENISTE, [1974] 1989, p. 82); b) “a semântica resulta de uma atividade do locutor que coloca a língua em ação” (BENVENISTE, [1966] 1976, p. 225); “A frase, criação indefinida, variedade sem limite, é a própria vida da linguagem em ação” (BENVENISTE, [1966] 1976, p. 139). Supondo que o sujeito individualiza a linguagem porque é, desde sempre, um indivíduo, supondo que cada ato de enunciação, porque manifestação da vontade de um indivíduo, seja, em tudo, individual, supondo que haja tantas variações quantos indivíduos, numa incomensurabilidade absoluta, então seria impossível arredar o pé da démarche saussureana e fundar uma linguística da enunciação. 
Contudo, se é a língua(gem) que se erige como fundante do sujeito e da subjetividade, então, a linguística da enunciação avulta como possível. É disso que Benveniste ([1966] 1976, p. 288) parece falar quando afirma que "É na instância de discurso na qual 'eu’ designa o locutor que este se enuncia como sujeito. É, portanto, verdade ao pé da letra que o fundamento da subjetividade está no exercício da língua”. Nessa perspectiva, não é o falante que individualiza a língua(gem), mas a língua(gem) que individualiza o falante. Para dizer de outro modo, a linguagem é potencialmente subjetivadora e dispõe de formas próprias para isso. Referindo-se à categoria de pessoa nos pronomes, diz Benveniste [1974] 1989, p. 69): “Quando alguém os [pronomes] pronuncia, este alguém os assume, e o pronome 'eu’, de elemento de um paradigma, se transforma em uma designação única e produz, a cada vez, uma nova pessoa”. Nesse caso, uma das tarefas da linguística da enunciação seria buscar e ver como funcionam, no maior número possível de línguas, os universais da linguagem humana (é a hipótese de fundo que subjaz aos estudos de Benveniste) com aptidão para individualizar os homens. Se, por um lado, a língua numa acepção semiótica força uma existência anônima, a enunciação, por outro, necessariamente individualiza a existência: falo, logo sou indivíduo. Trata-se de uma espécie de o 'verbo se faz carne’: me nomeio 'eu’, me declaro uma pessoa, me instituo 'sujeito'. 'Eu’ é uma palavra mágica que faz o falar acontecer-ser. Afinal, sentencia Benveniste ([1966] 1976, p. 285), “a linguagem ensina a própria definição do homem”.

Não raramente as duas perspectivas - sujeito a priori funda a subjetividade na língua(gem) ou a língua(gem) funda o sujeito - aparecem em sucessão: "É na instância de discurso na qual 'eu’ designa o locutor que este se enuncia como ‘sujeito'. [...] Se quisermos refletir bem sobre isso, veremos que não há outro testemunho objetivo da identidade do sujeito que não seja o que ele dá assim, ele mesmo sobre si mesmo” (BENVENISTE, [1966] 1976, p. 288). No primeiro período desta citação, parece vigorar a ideia de que é a língua(gem) que funda o sujeito, ao passo que, no segundo, é a ideia de que há um sujeito anterior à enunciação que, ao se exprimir pela língua(gem), dá um testemunho objetivo de sua identidade.

Embora esse jogo que alterna a relação de causa e efeito entre língua(gem) e sujeito tenha possibilitado uma aproximação linguística, quer dizer, científica da enunciação, não se pode ignorar o tom humanista, quer dizer, não científico, de que se reveste a categoria do sujeito em Benveniste. Por exemplo, no excerto seguinte: ““Eu’ designa aquele que fala e implica ao mesmo tempo num enunciado de responsabilidade de 'eu'; dizendo 'eu', não posso deixar de fala de mim” (BENVENISTE, [1966] 1976, p. 250), nuances variadas de sentido podem ser 
observadas. A afirmação ““Eu’ designa aquele que fala” soa como um enunciado adequado à linguística, mas o que vem depois parece carecer da objetividade exigida para merecer o estatuto de 'ciência'. É inegável a ressonância de humanismo jurídico em "implica ao mesmo tempo num enunciado de responsabilidade de 'eu'”, assim como é inegável a ressonância de idealismo romântico em “dizendo 'eu', não posso deixar de fala de mim”. É como se não se pudesse falar de sujeito em língua(gem) sem recair no humanismo. Essa oscilação entre um sujeito que se torna sujeito por dizer 'eu', um sujeito que se expressa ao dizer 'eu’ e um sujeito que se torna responsável pelo que diz, quando diz 'eu’ ressurge em muitos outros momentos da obra de Benveniste.

Embora sua maneira de pensar a questão do sujeito e da subjetividade se revele nitidamente tingida pelas cores do idealismo humanista, em suas versões romântica e jurídica, a historicidade do sentido de 'agente' (sujeito de) que, sob o signo do antropocentrismo, se sobrepõe ao sentido de 'paciente’ (sujeito $a$ ), é obliterada pela tese do fundamento linguístico da subjetividade. Se o fundamento do sujeito e da subjetividade é a categoria de pessoas, se a categoria de pessoa é uma categoria de linguagem, se a linguagem está na natureza do homem, então, o sujeito e a subjetividade têm a idade do homem.

Entretanto, a naturalização da interpretação do enunciador como um 'sujeito de', que está na base da linguística da enunciação, não passa despercebida a Michel Pêcheux. Ancorado no marxismo althusseriano, ele vê o 'sujeito de’ como um efeito ideológico. Refere-se ao esquecimento das mediações que faz o sujeito aparecer como causa sui como 'efeito Münchhausen’ (PÊCHEUX, 1975), inspirando-se, provavelmente, em Nietzsche (1982, p. 30), na crítica que o filósofo alemão faz ao 'livre arbítrio', à ‘vontade livre’ ou à ‘autonomia’ do indivíduo: “essa aspiração em tomar a inteira e última responsabilidade dos seus atos, aliviando Deus, o universo, os antepassados, o acaso, a sociedade, não é senão o desejo de ser precisamente essa causa sui e de se puxar a si mesmo pelos cabelos, com uma temeridade que ultrapassa a do barão Münchhausen, para sair do pântano do nada e entrar na existência”.

No rastro do que pensa Louis Althusser sobre ideologia, Pêcheux ensaia uma explicação para o funcionamento nas práticas discursivas do que nomeia como efeito Münchhausen. Paralelamente à tese “A ideologia interpela os indivíduos em sujeitos” (ALTHUSSER, 1985, p. 93), Pêcheux dirá que são os discursos que interpelam os indivíduos em sujeitos de seu discurso. Essas teses invertem completamente a epistemologia idealista. Com elas, a ideologia 
e o discurso deixam de ser vistos como tendo origem nos sujeitos e passam, inversamente, a ser vistos como sendo constituidores dos sujeitos.

Segundo Althusser (1978, p. 68), “a filosofia burguesa apoderou-se da noção jurídicoideológica de sujeito, para fazer dela [...] sua categoria filosófica no. 1, e para pôr a questão do sujeito do conhecimento [...], da moral e da história”. E então Pêcheux (1975, p. 143), complementa: "isso não significa que o efeito ideológico da interpelação seja restrito a essas novas relações sociais (relações jurídico-ideológicas), simplesmente elas constituem uma nova forma de assujeitamento, a forma plenamente visível da autonomia”.

O processo ideológico de interpelação pode sugerir que a constituição do sujeito se faz num acontecimento histórico datado na vida do indivíduo, ou ainda que o sujeito se alterna com o não-sujeito, ou seja, que o processo de interpelação é descontínuo. Porém, se, como afirma Althusser (1985, p. 98), a Ideologia é eterna, o processo de interpelação também o é: “os indivíduos são sempre/já sujeitos”. Do fato de a interpelação funcionar já desde sempre decorre uma espécie de naturalização da 'forma-sujeito' que, automaticamente, passa a ser tomada sob a forma de evidência. "E, como todas as evidências, [...] a evidência de que você e eu somos sujeitos é um efeito ideológico, o efeito ideológico elementar” (ALTHUSSER, 1985, p. 94). Sob esse efeito de evidência, o homem aparece naturalmente na forma de um 'sujeito de'. A Ideologia impõe as evidências como algo a ser automaticamente 'reconhecido'. Reconhecer-se sempre já sujeito significa, por exemplo, desconhecer/esquecer que "o teatro da consciência (eu vejo, eu penso, eu falo etc.) é observado dos bastidores, lá de onde se pode captar que se fala do sujeito, que se fala ao sujeito, antes que o sujeito possa dizer: 'Eu falo'” (PÊCHEUX, 1975, p. 138). O sujeito que é efeito da Ideologia passa a ser tomado como sua causa e causa sui, ou seja, como um sujeito que se erige a partir do nada, puxando-se pelos cabelos, como o barão de Münchhausen.

Outra tese de Althusser (1985, p. 88 e 93) incorporada à análise de discurso por Pêcheux é a de que “A Ideologia tem uma existência material” que se desdobra em “só há prática através de e sob uma ideologia” e "só há ideologia pelo sujeito e para o sujeito”. Isso significa que, apesar de se constituir como representação imaginária do real pelos sujeitos, a Ideologia determina-lhes os comportamentos, as atitudes e as práticas. Althusser cita o caso da ideologia religiosa vinculada à igreja católica como aparelho ideológico. Se um indivíduo crê em Deus, ele representa essa crença como vindo de si (é a tese da interpelação do indivíduo em sujeito). Suas práticas ecoam essa ideologia e seus rituais: o sujeito que se diz "católico" costuma ir à 
missa, se benzer, se ajoelhar, se confessar, comungar, rezar, repetir litanias, conversar com Deus, etc. Faz tudo isso como se estivesse tão somente seguindo os ditames de sua própria consciência, como se estivesse agindo "livremente". E uma das formas de existência material de qualquer ideologia é o discurso, dirá Pêcheux. Por exemplo, se há o catolicismo como ideologia, há também um discurso católico que circula em variados gêneros discursivos (evangelhos, orações, hagiografias, ladainhas, cânticos, ritos verbais de batismo, matrimônio e extrema-unção, etc.).

Para explicar a correlação entre discurso e ideologia, Pêcheux propõe duas teses. A primeira delas afirma que “o sentido de uma palavra, expressão ou proposição, etc. não existe em si mesmo, mas é determinado pelas posições ideológicas colocadas em jogo no processo sócio-histórico no qual [...] são produzidas (ou seja, reproduzidas)” (PÊCHEUX, 1975, p. 144). Por meio dessa tese, pretende mostrar que as unidades linguísticas não têm um sentido literal ligado a seus significantes (como supõe a linguística imanente), nem também um sentido completamente novo, contingente, individual a cada manifestação de linguagem (como supõe a linguística da enunciação). Palavras, expressões e proposições têm seu sentido determinado por “formações discursivas” que são uma forma de existência material das ideologias no domínio da linguagem. Por formação discursiva, Pêcheux (1975, p. 144) designa "aquilo que, numa formação ideológica dada, isto é, a partir de uma posição dada numa conjuntura dada, determinada pelo estado da luta de classes, determina o que pode e deve ser dito”. Numa dada formação social, as formações discursivas, assim como as formações ideológicas, não existem de modo puro, não são independentes umas das outras, elas se imbricam formando um 'todo complexo com dominante’ que Pêcheux (1975, p. 162) chama de ‘interdiscurso’.

Além de serem o sítio dos sentidos, as formações discursivas também realizam o processo de interpelação dos indivíduos em sujeitos de 'seu’ discurso, como já mencionado anteriormente. Se o discurso é uma prática ideológica, os agentes dessa prática só serão reconhecidos como 'agentes' se se revestirem da 'forma-sujeito'. Contudo, como afirma Althusser (1978, p. 67), “o fato de que sejam necessariamente sujeitos não faz dos agentes ('suportes') das práticas sócio-históricas o nem os sujeito(s) da história (no sentido filosófico do termo: sujeito de). Os agentes-sujeitos só são ativos na história sob a determinação das relações de produção e de reprodução, e em suas formas”. Quer dizer, os agentes (suportes) dos discursos não são sujeitos do discurso, mas sujeitos no/pelo discurso, ao serem interpelados a ocupar o lugar vazio, disponível a quem quer que, na forma do livre consentimento, assuma o 
viés interpretativo em jogo. A questão não é, pois, quem foi que falou e se disse o que queria dizer, mas que posição pode e deve ocupar um indivíduo para, ao falar a partir de uma dada formação discursiva, ser considerado um sujeito de. Como afirma Foucault (1986, p. 142), “Não importa quem fala, mas o que ele (sujeito-falante) diz não é dito de qualquer lugar”. Isso significa que, conservados os lugares dos enunciadores, o emprego de uma mesma unidade linguística tenderá a produzir o mesmo efeito de sentido, ao passo que, mudados os lugares, o emprego do que parece ser uma mesma unidade linguística resultará certamente em efeitos de sentido diversos.

Nessa perspectiva, o discurso não pode ser visto como uma sequência linguística fechada sobre si mesma, resultante de um ato de apropriação da língua por um sujeito, mas como um contínuo em que, sem começo e nem fim, sempre se está imerso. Isso desautoriza a tese da linguística enunciativa de que o discurso é uma "instância única e discreta” que tem como centro de referência o ego-hic-nunc. Também parece desautorizar a assunção do discurso como 'diálogo', se se toma diálogo com alternância de turnos entre dois sujeitos, como reversibilidade entre eu-tu. Interpelados por uma mesma formação discursiva, os enunciadores empregam a língua para significar uma relação comum ao mundo. Uma formação discursiva interpela os indivíduos em sujeitos, quer dizer, produz os sujeitos, “com, simultaneamente, aquilo que lhes é dado ver, compreender, fazer, temer, esperar e falar” (PÊCHEUX, 1975, p. 146). Isso permite ao enunciador experimentar/imaginar/representar o lugar do enunciatário a partir de seu próprio lugar e vice-e-versa: “Como se eu que falo estivesse no lugar onde alguém me escuta”, diz propriamente Pêcheux (1975, p. 153). Versos do poeta Paul Eluard (1968, p. 426): “Je suis un étrange animal/mes oreilles te parlent/ma voix t'ecoute et comprend”, aludem intuitivamente à comunidade e à alteridade do sentido e não à sua individualidade, aludem à travessia do enunciador e do enunciatário pelo discurso do Outro. E é apenas no Outro que enunciador e enunciatário se escutam mutuamente. Pode parecer paradoxal, mas não existe DIálogo de dois, apenas de três - TRiálogo. Enunciador e enunciatário dialogam não entre si, mas mediados pelo Outro, ou seja, pela formação discursiva. No jogo do fazer sentido, eles se encontram no Outro.

Admitindo que o(s) sentidos e os sujeitos se constituem sempre no interior de uma formação discursiva, Pêcheux passa à discussão da segunda tese: “Toda formação discursiva dissimula, pela transparência do sentido que nela se constitui, sua dependência com relação ao ‘todo complexo com dominante’ das formações discursivas (ou interdiscurso), intrincado no 
complexo de formações ideológicas” (PÊCHEUX, 1975, p. 146). Se a primeira tese afirma que o sentido e o sujeito dependem de uma formação discursiva, a segunda explicita o processo de dissimulação dessa dependência. O interdiscurso fornece/impõe os sentidos sob a forma da universalidade e da evidência - é evidente que tal palavra, tal expressão ou tal proposição significa o que o sujeito diz.

As duas teses propostas por Pêcheux permitem avançar no exame da forma-sujeito como sujeito do discurso. O sujeito se 'esquece' daquilo que o determina (esquecer, nesse caso, não significa apagar da memória algo que se sabia, mas encobrir a 'causa' do sujeito no interior de seu 'efeito', de tal forma que o 'efeito' apareça com causa). O sujeito do discurso não pode reconhecer seu assujeitamento à formação discursiva dominante que faz parte do interdiscurso porque esse assujeitamento se realiza sob a forma da autonomia, quer dizer, os sujeitos são produzidos com causa sui, ao menos no mundo presidido pela ordem antropocêntrica e por formações socioeconômicas capitalistas, onde as relações jurídicas se universalizaram concomitantemente com a universalização da circulação do dinheiro, das mercadorias e dos trabalhadores 'livres'. Destarte, “a forma-sujeito do discurso, na qual coexistem, indissociavelmente, interpelação, identificação e produção de sentido, realiza o nonsense da produção do sujeito 'como causa de si' sob a forma da evidência primeira” (PÊCHEUX, 1988, p. 295). E, assim, da visão do idealismo como uma posição epistemológica passa-se à visão do idealismo como "funcionamento espontâneo da forma-sujeito" (PÊCHEUX, 1975, p. 148). Na perspectiva da análise de discurso, romantismos e teorias da enunciação são exemplos do desconhecimento do funcionamento da forma-sujeito e do mecanismo de interpelação/identificação/determinação que produz o sujeito no lugar onde só há o Outro. No horizonte desse mal-entendido, românticos e teóricos da enunciação fazem do sujeito de o ponto de partida, fazem do 'efeito’ a 'causa'.

\section{Considerações finais}

O capítulo escrito por Benveniste conta entre os primeiros na história da chamada linguística da enunciação e o escrito por Pêcheux, entre os primeiros na história da chamada análise de discurso. O que os levou a ultrapassar os limites da linguística da língua foi a ressignificação do sentido, marginalizado entre os imanentistas. Ambos viam a significação como o próprio ser da língua(gem). Era importante demais para ficar na lixeira da linguística 
ou ser reduzida à teoria clássica do signo que postulava, em nível de sistema, a união indissolúvel de um significante e um significado.

Benveniste acabou por fundar a linguística da enunciação ao mostrar que nem todo signo podia ser explicado conceitualmente como a união de um significante e um significado fixos no léxico da língua. Ele revelou a existência dos chamados indivíduos linguísticos, significantes vazios, cujos significados só são explicitados quando empregados por um falante no exercício da enunciação. Dentre esses signos vazios, figuram aqueles que expressam as categorias de pessoa, tempo e lugar, tendo ao centro aquele que expressa a categoria de subjetividade, ou seja, aquele que nomeia o sujeito, o ‘eu’ a quem se atribui o papel de converter a língua em enunciação.

Pêcheux acabou por fundar a análise de discurso ao mostrar que o sentido não estava nas palavras isoladas dentro de um sistema, mas sim nos usos que eram feitos delas em condições sociais e históricas específicas. Para ele, o chamado sentido literal, tido como significado conceitual sistemicamente atado ao significante, é apenas um efeito de sentido que se explica pela dominância de um discurso numa conjuntura dada. Também ele vai se preocupar com o funcionamento do sujeito no discurso.

Ambos - Benveniste e Pêcheux - desejaram reintroduzir os aspectos semânticos da língua(gem) nos estudos linguísticos, e, nesse movimento, explodiram a clausura do imanentismo e abriram a brecha por onde passaram o mundo exterior e o homem. Afinal, era um paradoxo que a linguística, considerada a precursora das ciências humanas, tivesse negado a presença do homem na língua, descartando-o juntamente com a fala. Contudo, um e outro diferem no modo de significar o homem que fala - o sujeito da enunciação ou do discurso - e os elementos do mundo que participam da produção de sentido.

Em Benveniste, o mundo exterior que participa da produção de sentido limita-se ao euaqui-agora da enunciação. Quer dizer, o sujeito é aquele que diz 'eu’ e o 'espaço' e o 'tempo' são aqueles em que o ato de enunciar ocorre, são, portanto, coordenadas empiricamente definidas a partir da circunstância imediata. Frequentes vezes o sujeito de Benveniste é revestido de um matiz psicológico e/ou filosófico humanista, é dotado de uma identidade essencial que se manifesta na enunciação, tida como o reino da liberdade, em contraponto à língua que o constrange com suas normas.

Já em Pêcheux, o mundo exterior que participa da produção de sentido não se define em termos das coordenadas empíricas, mas sim de condições sócio-histórico-ideológicas que 
caracterizam uma dada conjuntura. O sentido do eu-aqui-agora do discurso não se constitui a partir de referentes recuperáveis na situação imediata de enunciação, mas sim de referentes discursivos. Toda enunciação, segundo Pêcheux, ocorre no interior de uma formação social, prenhe de ideologias que se materializam em discursos, formando o interdiscurso ou a memória discursiva de uma época. Assim, o sujeito da enunciação não tira de si mesmo o que diz, mas sim das sucessivas identificações/posições com que sua história de vida foi/vai sendo tecida. O sentido de “autor” que acompanha aquele que diz ‘eu’ não vem nem de um signo em estado de léxico e nem de um referente da situação imediata, mas vem de um discurso jurídico, naturalizado já nos mais de quinhentos anos de vigência da ordem antropocêntrica, que faz do sujeito a um sujeito de, que o torna responsável pelo que diz, podendo, inclusive, ser criminalizado em casos de injúria, difamação, disseminação de preconceitos contra minorias, plágio, etc.

Morto na linguística imanente, o sujeito da fala foi ressuscitado na linguística da enunciação e na análise de discurso, na primeira como um homem uno, como portador de um substrato original pronto para irromper nos enunciados e, na segunda, como um sujeito dividido, atravessado por muitas vozes, que não cessa de dizer: “C’est faux de dire Je pense: on devrait dire on me pense - pardon du jeu de mot. Je est un autre.” (RIMBAUD, 1972, p. 248). Enquanto o linguista da enunciação, no que conservou do idealismo e da psicologia, se interrogava sobre o ser do homem e sua subjetividade na língua(gem), o analista de discurso, no que tinha do materialismo histórico e da psicanálise, se perguntava sobre o Outro que, desde sempre, ocupa o suposto núcleo autêntico e estável do nosso ‘eu’. Como afirma lapidarmente Foucault (1986, p. 151), "nós somos diferença: nossa razão é a diferença dos discursos, nossa história é a diferença dos tempos, nosso eu é a diferença das máscaras". [...] a diferença, longe de ser a origem esquecida e recoberta, é a dispersão que somos e que fazemos”.

E, uma vez ressuscitado, o sujeito não finda de ser relido e reescrito no fecundo terreno da linguística da enunciação e/ou do discurso.

\section{Referências Bibliográficas}

ALTHUSSER, L. Resposta a John Lewis. Rio de Janeiro: Graal, 1978. 168p.

Aparelhos ideológicos de Estado. Rio de Janeiro: Graal, 1985. 128p.

BENVENISTE, É. Problemas de Linguística Geral I. São Paulo: Companhia Editora Nacional, [1966] 1976. 383p. 
. Problemas de Linguística Geral II. Campinas: Pontes, [1974] 1989. 298p.

. Estrutura das relações de pessoa no verbo. In: Problemas de Linguística

Geral I. São Paulo: Companhia Editora Nacional, [1946] 1976, p. 247-259.

A natureza dos pronomes. In: Problemas de Linguística Geral I. São Paulo: Companhia Editora Nacional, [1956] 1976, p. 277-283.

Da subjetividade na linguagem. In: Problemas de Linguística Geral I. São Paulo: Companhia Editora Nacional, [1958] 1976, p. 285-293.

As relações de tempo no verbo francês. In: . Problemas de Linguística Geral I. São Paulo: Companhia Editora Nacional, [1959] 1976, p. 260-276.

Os níveis da análise linguística. In: Problemas de Linguística Geral I. São Paulo: Companhia Editora Nacional, [1962] 1976, p. 127-140.

A forma e o sentido na linguagem. In: Problemas de Linguística Geral II. Campinas: Pontes, [1966] 1989, p. 220-242.

. Estruturalismo e linguística. In: Problemas de Linguística Geral II. Campinas: Pontes, [1968] 1989, p. 11-28.

. Semiologia da língua. In: Problemas de Linguística Geral II. Campinas: Pontes, [1969] 1989, p. 43-67.

O aparelho formal da enunciação. In: Problemas de Linguística Geral II. Campinas: Pontes, [1970] 1989, p. 81-90.

ELUARD, P. Oeuvres complètes. Paris: Gallimard, 1968. 1760p.

FOUCAULT, M. A arqueologia do saber. Rio de Janeiro: Forense, 1986. 240p.

HAROCHE, C. Faire dire, vouloir dire: la détermination et la désambiguïsation dans la grammaire. Paris: PUL, 1983. 226p.

NIETZSCHE, F. Para além do bem e do mal. Lisboa: Guimarães Editores, 1982. 224p.

NORMAND, C. Leituras de Benveniste: algumas variantes sobre um itinerário demarcado. Letras de Hoje. Porto Alegre, v.44, n.1, p.12-19, jan./mar. 2009.

ONO, A. La notion d'énonciation chez Émile Benveniste. Limoges: Lambert-Lucas, 2007. 236p.

PÊCHEUX, M. Les vérités de la Palice. Paris: Maspero, 1975. 280p. 

1988. 318p.

RIMBAUD, A. Oeuvres complètes. Paris: Gallimard, 1972. 1312p.

ROBIN, R. História e linguística. São Paulo: Cultrix, 1977. 327p.

SAUSSURE, F. Curso de linguística geral. São Paulo: Cultrix, 1975. 280p. 